\title{
ANALISIS INFORMASI KEUANGAN DAN PENERAPAN AKUNTANSI PADA BENGKEL MOBIL/TRUK AMANK
}

\author{
Dewi Yuliyanti ${ }^{1)}$ Dokman Marulitua Situmorang ${ }^{2)}$ \\ ${ }^{1}$ Universitas Terbuka, ${ }^{2}$ Institut Teknologi dan Bisnis Kristen Bukit Pengharapan \\ 1'dewivulivanti28@gmail.com, ${ }^{2}$ van.stmng1985@gmail.com
}

\begin{abstract}
Abstrak
Akuntansi dapat diartikan sebagai "bahasa bisnis" karena akuntansi adalah sebuah sistem informasi yang menyediakan laporan - laporan bagi pihak-pihak yang berkepentingan (stakeholders) mengenai aktivitas ekonomi dan kondisi suatu perusahaan. Usaha Mikro Kecil dan Menengah (UMKM) merupakan kelompok pelaku ekonomi terbesar dalam perekonomian Indonesia dan salah satu penopang perekonomian. Permasalahan yang dihadapi UMKM adalah terkait dengan pengelolaan dana karena itu merupakan faktor kunci yang dapat menyebabkan keberhasilan atau kegagalan UMKM. Hal ini mengharuskan UMKM untuk menerapkan akuntansi dalam menjalankan usahanya. Penelitian ini bertujuan untuk mengetahui dan menganalisis informasi keuangan dan penerapan akuntansi pada Usaha Mikro Kecil dan Menengah (UMKM) serta cara mengatur keuangan pada masa pandemi Covid-19. Sampel dalam penelitian ini menggunakan salah satu jenis bisnis yaitu Bengkel Mobil atau Truk "AMANK" di Pangkalan Bun. Data yang dipergunakan adalah data primer yang diperoleh melalui hasil wawancara dan kuesioner. Teknik analisis dari penelitian ini adalah teknik analisis deskriptif kualitatif. Hasil penelitian ini menunjukkan bahwa pencatatan akuntansi di Bengkel Amank belum maksimal. Hal ini terjadi karena minimnya pengetahuan, pemahaman serta kesadaran akan pentingnya penerapan akuntansi secara lengkap terutama dalam proses penyusunan laporan keuangan dalam rangka memperoleh informasi tentang kegiatan usaha selama satu periode akuntansi.
\end{abstract}

Kata Kunci : Akuntansi, Laporan Keuangan dan Usaha Mikro Kecil dan Menengah (UMKM)

\begin{abstract}
Accounting can be interpreted as "the language of business" because accounting is an information system that provides reports for interested parties (stakeholders) regarding the economic activity and condition of a company. Micro, Small and Medium Enterprises (MSMEs) are the largest group of economic actors in the Indonesian economy and one of the pillars of the economy. The problems faced by MSMEs are related to fund management because it is a key factor that can lead to the success or failure of MSMEs. This requires MSMEs to apply accounting in running their business. This study aims to identify and analyze financial information and the application of accounting for Micro, Small and Medium Enterprises (MSMEs) and how to manage finances during the Covid-19 pandemic. The sample in this study used one type of business, namely the "AMANK" Car or Truck Repair Shop in Pangkalan Bun. The data used are primary data obtained through interviews and questionnaires. The analysis technique of this study is a qualitative descriptive analysis technique. The results of this study indicate that the accounting records at the Amank Workshop are not optimal. This occurs because of the lack of knowledge, understanding and awareness of the importance of a complete accounting application, especially in the process of preparing financial reports in order to obtain information about business activities during one accounting period.
\end{abstract}

Keywords: Accounting, Financial Statements and Micro, Small and Medium Enterprises (UMKM) 


\title{
1. Pendahuluan
}

Di negara Indonesia Usaha Mikro Kecil dan Menengah (UMKM) merupakan kelompok pelaku ekonomi terbesar untuk mendorong pembangunan ekonomi. Salah satu tantangan utama yang dihadapi oleh UMKM adalah terkait dengan pengelolaan dana. Metode dalam pengelolaan dana pada UMKM adalah dengan menerapkan akuntansi dengan baik. Dengan demikian, akuntansi menjadikan UMKM dapat memperoleh informasi keuangan yang penting dalam menjalankan usahanya antara lain informasi kinerja perusahaan, informasi posisi dana perusahaan, informasi perubahan modal pemilik, informasi pemasukan dan pengeluaran kas. Akuntansi yang memadai maka UMKM dapat memenuhi persyaratan dalam pengajuan kredit berupa laporan keuangan, mengevaluasi kinerja, mengetahui posisi keuangan dan menghitung pajak (Warsono, 2010). Metode yang digunakan pada UMKM adalah metode berbasis kas yang mengakui pendapatan dan beban ketika kas diterima atau dikeluarkan. Salah satu UMKM yang membutuhkan akuntansi adalah usaha bengkel yang dikelola oleh Bapak Suryani meliputi pencatatan dan pelaporan keuangan untuk mengetahui posisi usahanya, jumlah piutang, hutang, persediaan, penjualan, dan laba tiap periode. Walaupun akuntansi menyediakan informasi keuangan yang penting bagi kesuksesan UMKM tetapi masih banyak yang belum menerapkan akuntansi dalam usahanya termasuk bengkel yang dikelola Bapak Suryani. Berdasarkan latar belakang yang telah diuraikan, maka masalah penelitian ini adalah masih banyak yang kurang menyadari peranan akuntansi bagi suatu usaha. Apabila akuntansi diterapkan dengan baik maka dapat membantu peningkatan usaha dan dapat menghasilkan suatu laporan yang dapat dipercaya sehingga dapat digunakan untuk keperluan pemilik usaha. Penelitian ini diharapkan dapat diterapkan oleh pemilik bengkel agar dapat menghadapi kendala-kendala dalam menjalankan usahanya dan dapat meningkatkan kualitas pencatatan akuntansi.

Persoalan penelitian yang dibahas adalah :

1. Bagaimana praktek pencatatan akuntansi di Bengkel "AMANK" yang dikelola oleh Bapak Suryani?

2. Bagaimana persepsi pemilik bengkel terhadap pencatatan akuntansi ?

3. Bagaimana cara pemilik bengkel dalam mengatur atau mengelola keuangan dalam masa pandemi Covid-19?

\section{Tinjauan Pustaka}

\begin{abstract}
Akuntansi
Financial Accounting Standard Boards mendefinisikan akuntansi yaitu suatu aktivitas jasa. Fungsinya menyediakan informasi kuantitatif, terutama yang bersifat keuangan, mengenai satuan-satuan ekonomi dan dimaksudkan untuk dipergunakan dalam pengambilan keputusan ekonomi yaitu dalam menetapkan pilihan yang tepat di antara beberapa alternatif tindakan. Tujuan umum akuntansi keuangan dan laporan keuangan adalah menyediakan informasi keuangan yang handal mengenai sumber daya dan kewajiban-kewajiban ekonomi dari suatu badan usaha. Dari pengertian tersebut akuntansi dapat ditinjau dua sisi sebagai berikut :
\end{abstract}

1. Sisi kegiatan; akuntansi berarti suatu seni mencatat, mengklasifikasi, dan meringkas data keuangan dengan cara yang berarti.

2. Sisi informasi yang dihasilkan; dalam hal ini akuntansi didefinisikan sebagai suatu sistem keuangan yang memberikan informasi penting yang dibutuhkan suatu 
organisasi agar dapat beroperasi secara efisien, mengetahui hasil kerja selama ini, dan merencanakan kegiatan ke depan agar lebih baik.

Kegiatan akuntansi meliputi sebagai berikut :

1. Pengidentifikasian dan pengukuran data yang relevan untuk suatu pengambilan keputusan.

2. Pemrosesan data yang bersangkutan kemudian pelaporan informasi yang dihasilkan.

3. Pengomunikasian informasi kepada pemakai laporan.

\section{Laporan Keuangan}

Laporan keuangan menurut Ikatan Akuntansi Indonesia (2000) dalam Standar Akuntansi Keuangan terdiri atas 5 (lima) komponen, yaitu laporan laba rugi, laporan perubahan ekuitas, neraca, laporan arus kas, dan catatan atas laporan keuangan. Pihakpihak yang berkepentingan terhadap laporan keuangan suatu perusahaan antara lain penanam dana atau modal yang membutuhkan informasi tentang posisi keuangan dan masa depan perusahaan, kreditur dan supplier perusahaan akan menilai sehat tidaknya keuangan perusahaan dan menilai risiko terhadap kredit yang diberikan kepada perusahaan.

Laporan laba rugi (income statement) merupakan laporan tentang kinerja keuangan suatu perusahaan yang melibatkan unsur pendapatan (revenue) dan biaya (expense). Dalam laporan ini disajikan jumlah pendapatan (revenue) dan biaya (expense) serta laba atau rugi (profit/loss) suatu perusahaan selama periode waktu tertentu. Pendapatan timbul atas pelaksanaan aktivitas perusahaan jasa (fees), pendapatan bunga, pendapatan dividen, pendapatan royalti dan pendapatan sewa (Surya,2012). Dari laporan ini kita dapat menganalisis perbandingan antara pendapatan dengan biaya untuk memperoleh sehingga dapat mengukur tingkat efisiensinya.

Laporan Perubahan Ekuitas (owner's equity statement) memberikan informasi tentang perubahan modal pemilik usaha selama periode waktu tertentu. Faktor-faktor yang mempengaruhi perubahan pada modal (ekuitas pemilik) adalah tambahan investasi yang dilakukan oleh pemilik, pendapatan yang diperoleh dan biaya yang dikeluarkan (laba/rugi) selama satu periode, dan pengambilan prive pemilik, baik mengurangi maupun menambah.

Neraca (balance sheet) merupakan laporan tentang posisi keuangan suatu perusahaan pada tanggal tertentu yang berisi daftar mengenai aset, kewajiban dan modal pemilik.. Oleh karena itu, neraca sering disebut sebagai potret dari posisi keuangan perusahaan, karena kondisi keuangan yang disajikan pada neraca tersebut hanya terjadi pada tanggal tertentu, yaitu tanggal penyusunan neraca. Diluar tanggal penyusunan neraca, kondisi keuangan tersebut bisa berubah.

Laporan Arus Kas adalah laporan yang menyajikan informasi tentang penerimaan dan pengeluaran kas selama periode tertentu. Informasi arus kas suatu perusahaan berguna bagi para pemakai laporan keuangan sebagai dasar untuk menilai kemampuan perusahaan dalam menghasilkan kas dan setara kas serta menilai kebutuhan perusahaan untuk menggunakan arus kas tersebut. Dalam metode berbasis kas, pendapatan dilaporkan pada periode dimana kas didapatkan dan diterima.

\section{Usaha Mikro Kecil dan Menengah}

Mengacu pada Pasal 1 UU 20/2008 tentang UMKM, ukuran usaha didefinisikan ke dalam empat kategori, yakni usaha mikro, kecil, menengah dan besar berdasarkan kekayaan bersih yang dimiliki dan hasil penjualan tahunan. Usaha mikro adalah usaha produktif milik perseorangan atau badan usaha perseorangan yang memiliki kekayaan bersih paling banyak Rp.50 juta, tidak termasuk tanah dan bangunan tempat usaha, serta 
berpenghasilan tahunan paling banyak Rp.300 juta. Usaha kecil adalah usaha produktif yang berdiri sendiri baik dilakukan oleh perorangan atau badan usaha yang bukan merupakan anak dari suatu perusahaan yang memiliki kekayaan bersih lebih dari Rp.50 juta dengan batas maksimal Rp.500 juta, tidak termasuk tanah dan bangunan tempat usaha serta berpenghasilan kisaran angka lebih dari Rp.300 juta dengan batas maksimal Rp.2,5 miliar. Sementara itu, usaha menengah adalah usaha ekonomi produktif yang berdiri sendiri dan dilakukan oleh perorangan atau badan usaha yang bukan anak dari suatu perusahaan yang memiliki kekayaan bersih lebih dari Rp.500 juta sampai dengan Rp.10 miliar, tidak termasuk tanah dan bangunan tempat usaha serta berpenghasilan tahunan berjumlah lebih dari Rp.2,5 miliar sampai dengan Rp.50 miliar.

Peranan UMKM sangat berpengaruh terhadap jumlah pendapatan negara dan mampu mengurangi angka pengangguran di masyarakat sekaligus juga meningkatkan kesejahteraan masyarakat. Hal ini terjadi karena banyaknya UMKM yang berdiri telah mampu mempekerjakan tenaga kerja yang sebelumnya pengangguran. Dengan begitu, kesejahteraan masyarakat akan meningkat dan terjamin.

\section{Metode Penelitian}

Teknik analisis yang digunakan dalam penelitian ini adalah analisis secara kualitatif dengan tipe deskriptif terhadap persepsi akuntansi dan praktek pencatatan akuntansi serta cara pengelolaan keuangan pada pelaku usaha Bengkel Amank. Data yang digunakan adalah data primer berupa hasil wawancara dan kuesioner terhadap pemilik usaha tersebut secara langsung tanpa melalui perantara. Data primer dalam penelitian ini adalah data yang diperoleh langsung dari pemilik usaha Bengkel Amank yaitu Bapak Suryani di Pangkalan Bun berupa hasil wawancara dan observasi.

\section{Hasil Penelitian Dan Pembahasan}

UMKM Bengkel Amank beralamat di Jalan Ahmad Yani RT. 31 Kelurahan Baru, Kecamatan Arut Selatan, Kabupaten Kotawaringin Barat, Provinsi Kalimantan Tengah yang dikelola oleh Bapak Suryani. Bengkel Amank merupakan bengkel yang menyediakan jasa perbaikan kendaraan roda empat terutama mobil dan truk. Usaha ini tergolong dalam jenis usaha jasa. Usaha ini dimulai pada tahun 2017 dengan pekerja sebanyak 3 orang.

Berdasarkan wawancara yang dilakukan peneliti dengan pemilik bengkel didapatkan hasil bahwa pemilik usaha tersebut hanya sedikit menerapkan pencatatan akuntansi pada usahanya. Hal ini terjadi karena menurut pemilik bengkel bahwa pencatatan akuntansi terlalu rumit dan menambah pekerjaan.

Tabel 1. pertanyaan yang diajukan

\begin{tabular}{clcc}
\hline NO. & \multicolumn{1}{c}{ Pertanyaan } & Ya $(\sqrt{ })$ & $\begin{array}{c}\text { Tidak }( \\
\text { X) }\end{array}$ \\
\hline 1. & Adanya buku kas masuk dan keluar & $\sqrt{ }$ & \\
2. & Membuat dokumen nota penjualan tunai & $\sqrt{ }$ & \\
3. & Membuat dokumen nota penjualan non tunai & $\sqrt{ }$ & \\
4. & Menggunakan pencatatan secara komputerisasi & & X \\
5. & Membuat jurnal setiap terjadi transaksi & & $\mathrm{X}$ \\
6. & $\begin{array}{l}\text { Adanya bukti transaksi pembelian barang yang } \\
\text { diperlukan }\end{array}$ & $\sqrt{ }$ & \\
7. & Memiliki laporan keuangan & & $\mathrm{X}$ \\
8. & Memahami manfaat laporan keuangan & & $\mathrm{X}$
\end{tabular}


9. Sumber Daya Manusia yang memadai

$\mathrm{X}$

10. Alat-alat yang digunakan efektif

Berdasarkan hasil jawaban dari pertanyaan yang peneliti ajukan masih banyak sistem akuntansi yang tidak diterapkan pada usaha Bengkel Amank karena kurangnya pengetahuan mengenai pembukuan akuntansi dan anggapan mereka jika pencatatan akuntansi itu sangat rumit serta pencatatan akuntansi harus dilakukan dengan seorang yang ahli dibidangnya karena pemilik bengkel tidak mempunyai pengetahuan dasar tentang akuntansi karena pendidikannya hanya sekolah dasar, sedangkan karyawannya berpendidikan sekolah menengah kejuruan dengan jurusan teknik sipil. Apabila pencatatan akuntansi dilakukan oleh seorang yang ahli di bidangnya, maka pemilik harus menambah karyawan dan mengakibatkan penambahan biaya gaji karyawan. Untuk menentukan laba usaha, pemilik hanya mencatat pendapatan yang diperoleh serta biaya pembelian sparepart dan biaya gaji, maka akan diketahui berapa laba yang didapatkan. Padahal masih ada biaya-biaya yang seharusnya dicatat seperti biaya listrik, biaya sewa tempat, dan biaya lainnya.

Tabel 2. pencatatan pendapatan dan pengeluaran Bengkel Amank

\begin{tabular}{|c|c|c|c|}
\hline Tanggal & Keterangan & Debet & Kredit \\
\hline $01 / 08 / 2020$ & $\begin{array}{l}\text { Jasa perbaikan Per Induk belakang dan depan } \\
\text { truk (Bapak Niko) }\end{array}$ & Rp. 610.000 & \\
\hline $04 / 08 / 2020$ & $\begin{array}{l}\text { Jasa Perbaikan Per Induk Depan dan Bushing } \\
\text { Per truk (Bapak Sigit) }\end{array}$ & Rp.390.000 & \\
\hline 06/08/2020 & $\begin{array}{l}\text { Jasa Perbaikan Per Belakang Nomor } 2 \text { dan } \\
\text { Per induk Depan truk (Bapak Amat) }\end{array}$ & Rp.515.000 & \\
\hline $10 / 08 / 2020$ & Pembelian Sparepart di Toko Tidar & & Rp.600.000 \\
\hline $12 / 08 / 2020$ & $\begin{array}{l}\text { Jasa Perbaikan dan Las Per Induk Belakang } \\
\text { dan Depan (Bapak Anto) }\end{array}$ & Rp.760.000 & \\
\hline $14 / 08 / 2020$ & $\begin{array}{l}\text { Jasa Perbaikan Per Induk Depan dan } \\
\text { Belakang serta Bushing Per truk (Bapak } \\
\text { Minto) }\end{array}$ & Rp.630.000 & \\
\hline $15 / 08 / 2020$ & $\begin{array}{l}\text { Jasa Perbaikan Per Belakang No } 7 \text { dan No } 2 \\
\text { truk (Bapak Agus) }\end{array}$ & Rp.365.000 & \\
\hline $18 / 08 / 2020$ & $\begin{array}{l}\text { Jasa Perbaikan Per Extra No } 1 \text { dan Per Induk } \\
\text { Belakang truk (Bapak Suripto) }\end{array}$ & Rp. 425.000 & \\
\hline $20 / 08 / 2020$ & Pembelian Sparepart di Toko Tidar & & Rp.795.000 \\
\hline $21 / 08 / 2020$ & $\begin{array}{l}\text { Jasa Perbaikan dan Las Per Induk Depan truk } \\
\text { (Bapak Syahroni) }\end{array}$ & Rp.415.000 & \\
\hline $24 / 08 / 2020$ & $\begin{array}{l}\text { Jasa Perbaikan Per Belakang No } 3 \text { dan Per } \\
\text { Induk Depan Truk (Bapak Niko) }\end{array}$ & Rp. 505.000 & \\
\hline $25 / 08 / 2020$ & $\begin{array}{l}\text { Jasa Perbaikan Per Depan No } 3 \text { dan Belakang } \\
\text { No } 7 \text { (Bapak Andi) }\end{array}$ & Rp.360.000 & \\
\hline $26 / 08 / 2020$ & $\begin{array}{l}\text { Jasa Perbaikan Per Induk Depan dan } \\
\text { Belakang truk (Bapak Faqih) }\end{array}$ & Rp.610.000 & \\
\hline $27 / 08 / 2020$ & $\begin{array}{l}\text { Jasa Perbaikan Per Belakang No } 2 \text { dan Depan } \\
\text { No } 3 \text { (Bapak Yahya) }\end{array}$ & Rp. 395.000 & \\
\hline $29 / 08 / 2020$ & $\begin{array}{l}\text { Jasa Perbaikan Per Induk Belakang dan Per } \\
\text { extra No } 1 \text { truk (Bapak Agung) }\end{array}$ & Rp.425.000 & \\
\hline $31 / 08 / 2020$ & Biaya Gaji Karyawan 2 orang & & Rp.3.000.000 \\
\hline
\end{tabular}




\begin{tabular}{lll} 
TOTAL & Rp.6.405.00 & Rp.4.395.000 \\
& 0 & \\
Laba Pendapatan & Rp.2.010.00 & \\
& 0 & \\
\hline
\end{tabular}

Berdasarkan hasil observasi langsung dilapangan, ada beberapa alasan yang mungkin perlu diperhatikan yang menyebabkan tidak adanya penyusunan laporan keuangan oleh pemilik bengkel tersebut sehingga menyebabkan kemampuan menyusun laporan keuangan tidak berpengaruh terhadap kinerja usaha mereka disebabkan karena pemilik bengkel :Lebih mengutamakan peningkatan kinerja usahanya dibandingkan membuat laporan akuntansi sebagai bukti kinerja usahanya.

1. Pemilik bengkel merasa sulit untuk meluangkan waktu untuk membuat laporan keuangan karena merasa laporan keuangan sangat rumit.

2. Kurangnya memperhatikan pengelolaan akuntansi karena menurut pemilik bengkel dampaknya tidak mempengaruhi langsung terhadap kelangsungan usahanya.

3. Pemilik bengkel merasa usahanya tidak cukup besar, sehingga tidak perlu untuk melakukan pencatatan akuntansi.

4. Kurangnya pengetahuan pemilik tentang pencatatan akuntansi, dan tidak adanya seseorang yang ahli dalam bidang akuntansi.

5. Dana yang digunakan untuk usaha sering bercampur dengan dana sendiri yang digunakan untuk pengeluaran biaya-biaya tanpa melakukan pencatatan akuntansi pada buku kas keluar.

\section{Pembahasan}

Dengan penerapan akuntansi yang baik dan memadai maka dapat membantu peningkatan usaha dan dapat menghasilkan laporan yang dapat dipercaya sehingga dapat digunakan untuk keperluan yang penting oleh pemilik usaha. Namun dalam penerapannya, akuntansi merupakan hal yang rumit bagi UMKM karena menurut mereka tidak ada waktu luang untuk menjalankan akuntansi. Faktor yang membuat akuntansi tidak dijalankan adalah tidak adanya ilmu dalam bidang akuntansi, dan apabila harus menambah pekerja yang ahli di bidang akuntansi artinya akan ada penambahan biaya gaji. Apabila UMKM telah melakukan pencatatan akuntansi dengan baik, akan mempermudah dalam proses pengajuan pinjaman ke pihak perbankan. Agar terciptanya pengelolaan keuangan yang baik maka diperlukan keharusan dalam pencatatan dan pelaporan keuangan.

Pada masa Covid-19 dampak yang sangat dirasakan oleh suatu negara yaitu dalam bidang ekonomi karena mempengaruhi pendapatan negara. Usaha Mikro, Kecil dan Menengah (UMKM) yang ada di Indonesia memberikan pengaruh yang cukup besar, sehingga di masa pandemi ini banyak dampak negatif yang dirasakan. Hal ini juga dirasakan pemilik bengkel tersebut karena pandemi ini menyebabkan turunnya kinerja dari sisi permintaan yaitu jasa perbaikan kendaraan karena mengganggu pendapatan sehingga menimbulkan macetnya pembayaran kredit. Pengelolaan keuangan yang dilakukan oleh pemilik usaha selama pandemi adalah mengurangi pengeluaran biaya seperti meminimalisir pembelian bahan yang digunakan serta menunda pengeluaran yang bisa ditunda. Adapun untuk pendapatan jasa yang diterapkan selama pandemi adalah lebih mengutamakan pendapatan jasa tunai. Sedangkan untuk pendapatan jasa non tunai menerapkan masa jatuh tempo yang cepat. Sehingga pengeluaran tidak melebihi dari pendapatan jasa.

Dukungan pemerintah terhadap UMKM selama pandemi Covid-19 diwujudkan dalam enam kebijakan yang dapat digolongkan dalam tiga kelompok kebijakan, yakni 
restrukturisasi kredit UMKM, kredit modal kerja, dan dukungan lainnya. Dukungan ini dilakukan pemerintah bekerja sama dengan Bank Indonesia (BI) dan Otoritas Jasa Keuangan (OJK). Kebijakan restrukturisasi kredit UMKM dilakukan dengan :

1. Relaksasi penilaian kualitas aset

2. Penundaan pokok dan subsidi bunga

3. Kredit modal kerja berbunga murah

4. Penjaminan kepada Askrindo dan Jamkrindo

5. Pemberian insentif PPh Final UMKM ditanggung pemerintah

6. Bantuan presiden produktif usaha mikro

Terdapat empat kriteria bagi calon penerima subsidi bunga yaitu pertama memiliki pembiayaan hingga 29 Februari 2020. Kedua, tidak termasuk dalam daftar hitam nasional. Ketiga, memiliki kategori performing loan lancer dihitung per tanggal 29 februari 2020. Keempat, memiliki NPWP atau mendaftar untuk mendapatkan NPWP. Dukungan pemerintah ini juga dirasakan oleh pemilik usaha bengkel, sehingga dengan subsidi bunga pemilik dapat membayar untuk biaya yang lainnya.

\section{Kesimpulan Dan Saran}

Dari hasil penelitian dan pembahasan diatas maka dapat disimpulkan bahwa tidak adanya penerapan akuntansi di Bengkel Amank yang dikelola Bapak Suryani. Pembukuan yang dibuat hanya terkait dengan pemasukkan pendapatan jasa dan biaya pembelian bahan-bahan serta sedikit biaya pengeluaran yang lainnya. Sehingga sangat sulit untuk mengetahui biaya yang dikeluarkan selama satu periode dan menentukan laba usaha karena hanya sedikit biaya-biaya yang tercatat. Hal ini menunjukkan bahwa pemilik bengkel tidak menerapkan akuntansi yang baik sebagai dasar dalam pengambilan keputusan serta pengajuan kredit untuk mendapatkan penambahan modal.

Pencatatan akuntansi pada kenyataanya masih menjadi hal yang sulit untuk Usaha Mikro Kecil dan Menengah (UMKM), sehingga saran dari penelitian ini adalah :

1. Diharapkan untuk UMKM dapat menerapkan akuntansi dengan baik dengan melakukan pencatatan akuntansi untuk mempermudah mendapat modal dari pihak kreditur dan mengetahui laba usahanya.

2. Adanya kesadaran pelaku usaha untuk melakukan pencatatan akuntansi.

3. Adanya peran pemerintah untuk mengawasi dan mendampingi dalam melakukan penerapan akuntansi dengan baik.

\section{Daftar Pustaka}

Anandi, Buyung Crismawan. (2020). Pengaruh Covid-19 Terhadap UMKM di Indonesia. Selasa 28 Juli 202011.00 WIB http:/genial.id/read-news/pengaruh-covid19terhadap-umkm-di-indonesia

Hendrian. (2014). BMP EKSI4101 Laboratorium Pengantar Akuntansi (edisi 2).Tanggerang Selatan.Penerbit Universitas Terbuka https://www.pustaka.ut.ac.id/lib/eksi4101-laboratorium-pengantar-akuntansi-edisi$\underline{21}$

Muhammad, Syamsudin. (2020). Dampak Pandemi Covid-19 Terhadap UMKM di

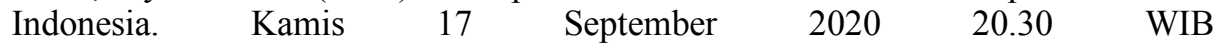
https://www.nu.or.id/post/read/123247/dampak-pandemi-covid-19-terhadapumkm-di-indonesia 
Sugiarto. (2014). BMP EKMA4115. Pengantar Akuntansi (edisi 2). Tanggerang Selatan. Penerbit Universitas Terbuka https://www.pustaka.ut.ac.id/lib/ekma4115pengantar-akuntansi-edisi-2-2/

Vincentius,Gitiyarko.Kebijakan Perlindungan dan Pemulihan UMKM di Tengah Pandemi $\begin{array}{lllll}\text { Covid-19.2020.Senin } & 31 & \text { Agustus } 2020 & 01.00 & \text { WIB }\end{array}$ https://kompaspedia.kompas.id/baca/paparan-topik/kebijakan-perlindungan-danpemulihan-umkm-di-tengah-pandemi-covid-19 